腸間膜血流障害によると思われる小腸の多発性狭窄の 1 例

\begin{tabular}{cccccc}
\multicolumn{7}{c}{ 八千代病院外科 } & \\
三浦 & 由雄 & 佐藤太一郎 & 七野 & 滋彦 & 秋田 幸彦 \\
片山 & 信 & 山本 英夫 & 加藤 & 庄次 & 宮田美智也
\end{tabular}

\title{
A CASE OF MULTIPLE STENOSIS OF SMALL INTESTINE DUE TO DISTURBANCE OF MESENTERIC BLOOD FLOW
}

\author{
Yoshio MIURA, Taichiro SATO, Shigehiko SHICHINO, \\ Yukihiko AKITA, Makoto KATAYAMA, Hideo YAMAMOTO, \\ Shoji KATO and Michiya MIYATA \\ Department of Surgery, Yachiyo Hospital
}

索引用語：晹間膜血流障害, 小腸多発性㹨害

I. はじめに

腸間膜血流障害による腸管の病変についての記述は 多いが1)，腸間膜の末梢微小血管の血流障害による小 腸の病変はまれである。最近われわれは胃癌手術後に 腸閉塞症状で発症した小腸の多発性狭窄を経験し，そ の病態が腸問膜の末梢微小血管の血流障害によるもの であると思われたので文献的考察を加えて報告する。

患者：32歳, 女性.

\section{II. 症 例}

主訴：腹痛, 呕吐.

既往歴：特記すべきことなし。

現病歴： 1 年前から心墖部痛と腰痛があった。検査 の経果 Borrmann 4 型の胃癌と診断された。昭和58年 8 月 10 日に根治的胃全摘と脾摘拉上び莁体尾部切除を 施行した. $\mathrm{H}_{0} \mathrm{~S}_{1} \mathrm{P}_{0} \mathrm{~N}_{2}$ であった. 再建は結腸後で空腸間 置法を用いた。術後経過は順調であったので術後 2 週 間目に mitomycin C 10mg を静注し, 術後24日目から 28 日間に断続的に Futraful を合計 $13.8 \mathrm{~g}$ 内服させた。 術後50日ごろから食後の左中腹部痛を訴えるように なった.さらに 1 週間後には食べると呕吐し, 水を飲 んでも腹痛を訴えるよらになった. IVHを再開し腸閉 塞の保存的治療を行った。血小板は術前は約20万/ $\mathrm{mm}^{3}$ であり, 術後50 60万 $/ \mathrm{mm}^{3}$ に増加したが化療施 行後減少して術後 56 日目は 11.3 万 $/ \mathrm{mm}^{3}$ となった。白 血球もこの時点で $1,200 / \mathrm{mm}^{3}$ まで減少した。抗癌剤に

$<1985$ 年 9 月 11 日受理 >別刷請求先: 三浦 由雄

₹446 安城市東栄町 $1-10-13$ 八千代病院外科
図 1 経過図

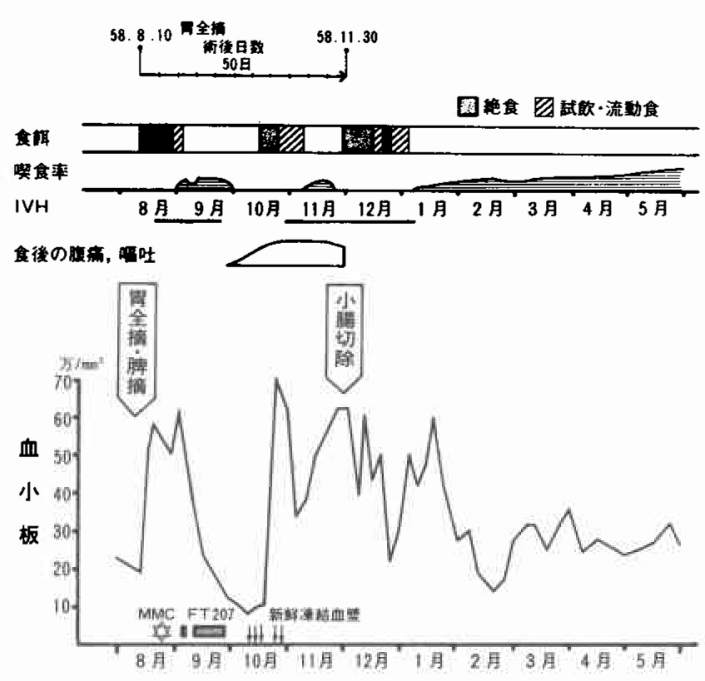

よると思われる白血球や血小板の减少に対して新鮮凍 結血浆を使用したところ末梢血の所見は回復し白血球

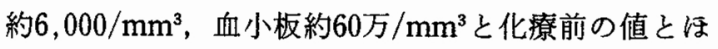
ぼ同じになった(図 1)。しかし腹痛, 呕吐は軽減しな かった。

術後52日に gastrografin による上部消化管造影を 施行したところ空腸上部で鉛管状狭窄を示し，その口 側抢よび肛門側の小腸拡張を認めた。術後69日に同じ 方法を繰り返したが同じ所見であった(図 2)，阻血性 腸炎を疑い術後77日に上腸間膜動脈と腹腔動脈をそれ ぞれ選択的に造影した。上腸間膜動脈系では第 4 空腸 動脈の分枝に造影剂の残留があり，あとゆっくり静脈 
因 2 上部消化管造影.空腸上部で鉛管状狭窄を示し, その口側䟙よび肛門側の小腸拡張を認めた。

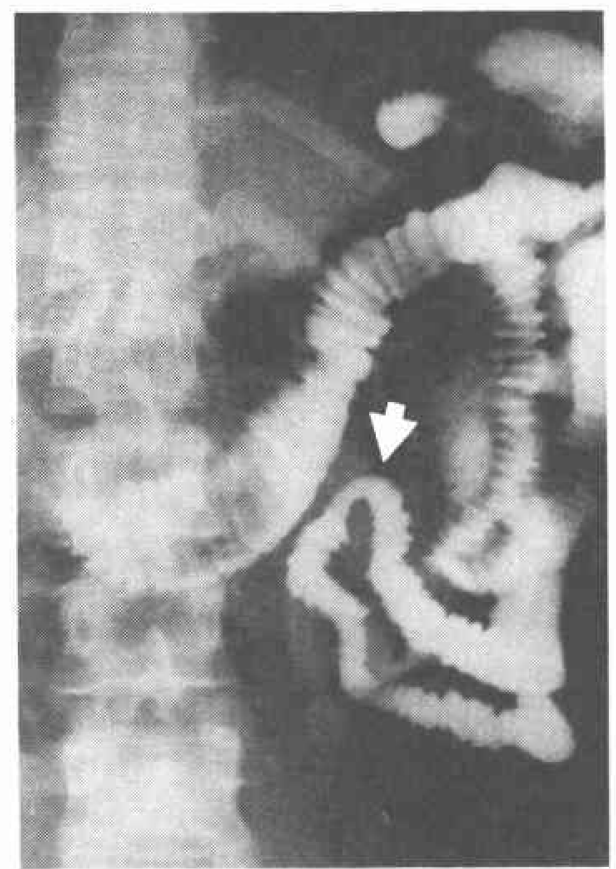

相を描出した(図 3)。これは低流量状態を示するのと 思われ，部位的にも空腸の鉛管状狭窄の部分とほぼ一 致した，腹腔動脈系には異常は認められなかった，術 後86日に施行したバリウムによる腸造影で小腸の多発 性狭窄を認めた，狭窄部の詳細を知るためにバリウム による小腸二重造影の施行したところ空腸上部に長さ 約 $20 \mathrm{~cm}$ の狭窄が 2 条認められた（図 4). 狭窄部の口 側だけでなく肚門側にも小腸の抾張が認められたため 阻血性腸炎による多発性狭窄と診断した。

腹痛之呕吐が続くため昭和58年11月30日（胃手術か ら112日)に開腹術を施行した。前回の手術創はヶロイ ド化していたが開腹すると腹壁一小腸, 小腸一小腸の 癒着は軽微であった。腹水は認めず，小腸全体で 8 力 所に狭窄を認めそれぞれ分節的にンーセージ様の硬さ で，その部分の浆膜は粗䊁になっており腸間膜に接し た部分には微細な血管新生を認めた。腸間膜動脈はよ く拍動を触れ, 動脈枝にも血栓はなく動脈硬化も認め

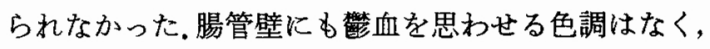
腸間膜静脈にも異常は認められなかった。狭窄部は示 指を通さぬ太さで回腸末端から口側へ $110 \mathrm{~cm} の$ 部位 から $275 \mathrm{~cm}$ の部位にわたって $165 \mathrm{~cm}$ の範囲で空腸招 よび回腸に分布していたが(図 5 )それぞれ切除し端々
図 3 上腸間膜動脈造影，第 4 空腸動脈の分枝に造影 剂の残留があり, あとゆっくり静脈相を抽出した。

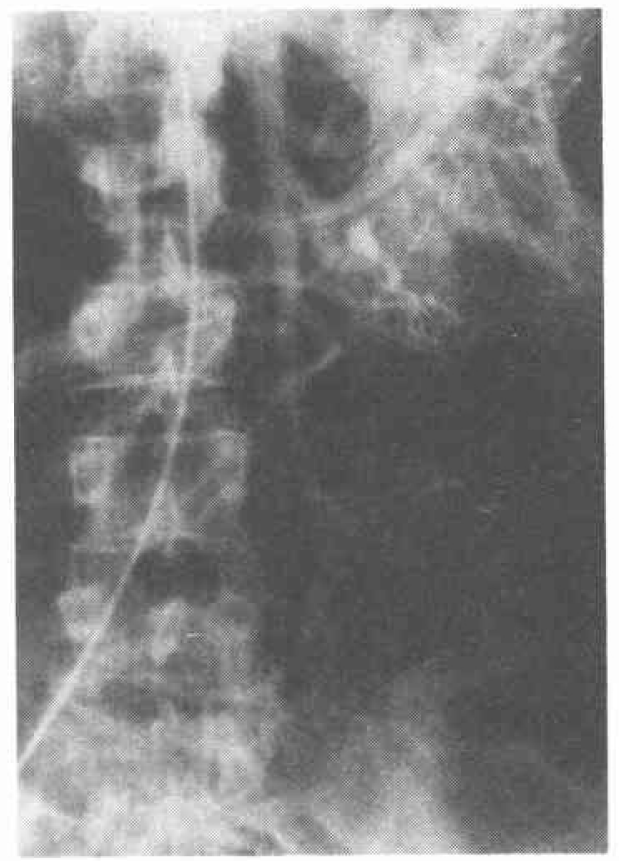

図 4 小腸二重造影. 空腸上部に長さ約 $20 \mathrm{~cm}$ の狭窄 が 2 条認められた。

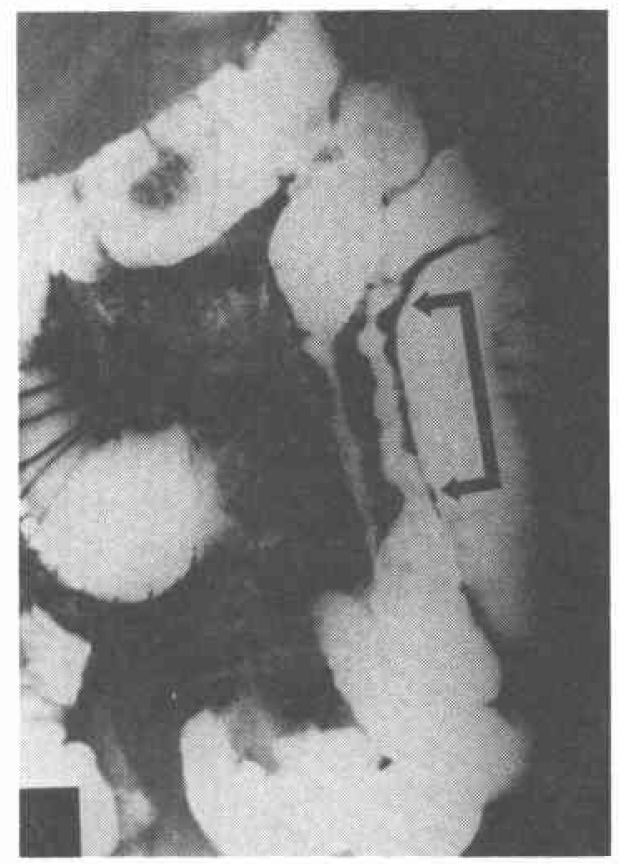


図 5 小腸狭窄部と切除標本粘膜面
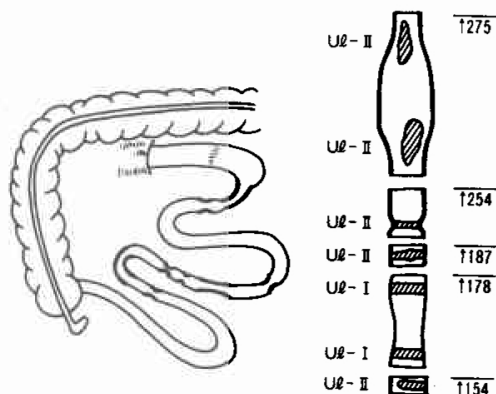

Ue-II $\frac{1154}{1148}$

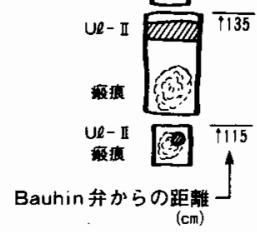

図 6 病理像. $\times 40 \mathrm{HE}$

粘膜下層の肥厚と著明な鬱血と炎症性細胞漫潤が認 められた。

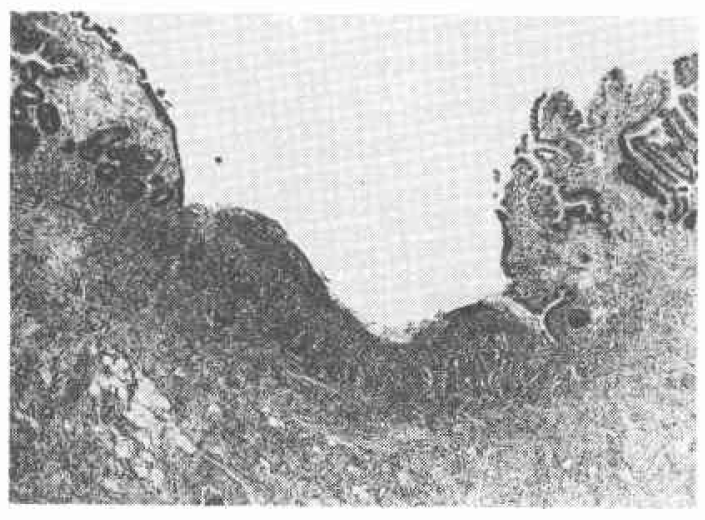

吻合を行った.

切除した小腸の長さは口側から順にそれぞれ16，4， $2,9,1.5,3,10,4.5 \mathrm{~cm}$ であった. 病変部の小腸の厚 さは4〜 $5 \mathrm{~mm}$ に達していた，粘膜面には輪状または島 状にUl-I ないし Ul-II の潰瘍が認められ一部は白色瘤 痕状になったものもみられた，病理組織学的にみると 粘膜下層の肥厚と著明な棪血と炎症性細胞浸潤が認め られた(図6)、へモジデリンを含むマクロファージや 癌細胞はみられず筋層の肥大や浆膜の肥厚, 肉芽腫も なく血管病変も認められなかった（表 1 ）。

術後は一時的に腹腔膿瘍や肺合併症があったが腸管 の通過障害はなく経口摂取量も次第に増加していっ た. 血小板数も正常に復して術後 8 力月の現在全く健
表 1 切除小腸の病理学的所見

\begin{tabular}{|c|c|c|c|c|c|c|c|c|}
\hline ロ則からの湏位 & 1 & 2 & 3 & 4 & 5 & 6 & 7 & 8 \\
\hline 切除鵑管の長さ (cm) & 16 & 4 & 2 & 9 & 1.5 & 3 & 10 & 4.5 \\
\hline 謴理の！ & 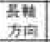 & 显状 & 瓄状 & 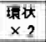 & 半環犾 & 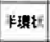 & 監桨 & 不正 \\
\hline 深 さ & $u e-1$ & Ua-1 & $U_{\boldsymbol{R}-1}$ & in- -1 & $\omega_{i-1}$ & $4 t-1$ & 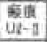 & $\begin{array}{l}\text { Sher } \\
\text { Ue }-\pi \\
\end{array}$ \\
\hline 浸 潣 細 胞 & $L N$ & LN & $\begin{array}{c}\text { N.L } \\
E\end{array}$ & LE & N & $\begin{array}{l}\text { E.E } \\
\text { HP }\end{array}$ & $N E$ & N \\
\hline \multirow{3}{*}{$\begin{array}{l}\text { 粘 } \\
\text { 膜 } \\
\text { 下 } \\
\text { 居 }\end{array}$} & + & + & + & \pm & + & + & + & + \\
\hline & + & + & \pm & + & - & + & - & - \\
\hline & \pm & + & \pm & - & \pm & - & \pm & \pm \\
\hline 籍 血 & H & H & H & + & + & H & H & + \\
\hline \multirow{3}{*}{ 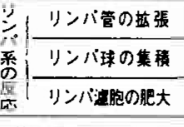 } & + & - & - & - & - & + & + & - \\
\hline & - & - & - & - & - & - & - & - \\
\hline & - & - & - & - & - & - & - & - \\
\hline 筇 雾の肥 大 & - & - & - & - & - & - & - & - \\
\hline \multirow[b]{2}{*}{ 唹 膜 } & - & - & - & - & - & - & - & - \\
\hline & H & + & + & $H$ & + & + & + & + \\
\hline 出 血 & - & + & \pm & + & - & \pm & + & \pm \\
\hline 肉 牙 & - & - & - & - & - & - & - & - \\
\hline
\end{tabular}

康である.

\section{III. 考 察}

小腸の多発性狭窄が発生した原因について考える。 いろいろな報告症例をみると一次的に膠原病 ${ }^{2)}$ 中 DIC なとの血管や血液の異常によるるのや，腸閉塞や腸狭 窄のための腸管内王六進による二次的な腸管壁の血流 障害によるものも考光られる。本症例では血液検查な ぞにて膠原病の所見は認められず，DICの状態でもな かった，腹腔内の癒着は軽度であり索状物も認められ ずこれらによる二次的な腸管壁の血流障害は考えら れない. 脾摘後の晹間膜静脈血栓 ${ }^{3}$ の発生が報告され ている，脾摘に限らず腹部手術後に腸間膜血流障害が

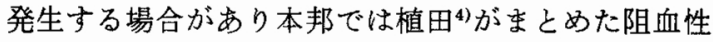
空腸炎の本邦報告例の $5 ち 4$ 例が腹部手術後に発生し たものである.脾摘後の腸間膜静脈血栓の症例につい て平岡5)は多くは欰小板増多を示していたとしている が, $\mathrm{Broe}^{6)}$ は自己の 5 例を詳細に検討し血小板増多が risk factor とはいえないと結論している. 自験例は脾 摘が施行されているが術後一過性に血小板増多をみた ものの抗癌剤のため血小板が減少している時に腸閉塞 症状が発生した。薬剤による小腸潰瘍の発生?る知ら れている. $\mathrm{KCl}$ 小腸潰瘍は腸管壁粘膜の阻血で発生す るとされて扣り，その他の薬剂でも小腸潰瘍を発生す る例が報告されているが自験例では $\mathrm{KCl}$ をはじめそ れらの薬剂は使用していなかった。 なた腹部外傷によ る小腸狭窄8も考光られない.クローン病などの特異 
的炎症疾患む病理組織像から否定される，放射線障害 も考兄られない，選択的血管造影の所見と合わせ本症 例は腸間膜血流障害による阻血性腸疾患之考兄られ た.

阻血性腸疾患は血流障害の発生部位により

1. 主要動脈閉塞 (血栓か塞栓か)

2. 腸管壁内微小血管閉塞

3. 静脈閉塞 (腸間膜静脈か門脈か)

4. 非閉塞性阻血の 4 型に分類される.自験例では開 腹時に腸間膜の主要動脈はよく触知され閉塞は認めら れなかった。をた腸間膜静脈および門脈にも閉塞は認 められなかった。非閉塞性阻血について Renton"14多 くは心疾患や高血圧患者でショック症状を伴って発生 する場合が多いことを示した，本症例には既往に心疾 患や高血压はなくショック症状るみられなかった，小 腸狭窄が広範囲にわたりしかも分節的に多数個所であ り，腸間膜に接した部分に徽細な血管新生を認めたこ とから，多数個所の腸間膜末梢あるいは腸管壁内の徽 小血管の閉塞が最む考兄られた。このような腸管壁内 の微小血管閉塞の症例は注とんど報告されていないが Ottinger ${ }^{10)}$ の報告した腸間膜血流障害136例のらちの 大きな動静脈に閉塞がない腸梗塞67例のなかに含まれ ていると考觉らる。

Boley ${ }^{11)}$ の動物実験によれば, イヌにセラミックガ ラス製の小球 $(35 \sim 100 \mu)$ を静注すると $2 \sim 3$ 週間後 に表層性潰瘍が発生し, 動注では小球の大きさや量に よって全層壊死や腸間膜対側の線状潰場または輪状潰 瘍などの種々の程度の病変を生じたという。

本症例の腸間膜血流障害の原因は明らかではない が，胃手術の際の腸間膜操作と脞体尾部切除による上 腸間膜静脈への影響に加えて脾摘による血小板増多が 誘因となったことが十分考党られる。

血流障害による小腸狭窄は多彩でその原因も種々で あり腸管壁の侵される深さや広がりもいろいろで深さ は粘膜のみのものから, 浆膜に達寸るものなど症例ご とに異なるほどで，広がりす全腸管にわたるすのから 本症例のよ5に継ぎはぎ状に分布するものや，分節状
のものなどがある，臨床症状に合わせて消化管造影で 経過を追らと共に, 血管造影を施行してその閉塞部位 や程度を知っておくことがこのような症例を治療する ために必要である.

\section{IV.まとめ}

胃癌手術後に発生した腸間膜末梢あるいは腸管壁内 微小血管閉塞による血流障害が原因と思われる小腸の 多発性狭窄の 1 例を報告し文献的考察を加兄た。

\section{文献}

1) Cooperman $M$ : Intestinal ischemia. New York, Futura Publishing Company Inc, 1983

2）桜井秀憲, 義岡郁雄, 河野 保注か：結節性動脈周 囲炎によると思われる胃小腸多発性潰湯の 1 治験 例. 外科 $34: 974-978,1972$

3) Balz J, Minton JP: Mesenteric thrombosis following splenectomy. Ann Surg 181: 126-128, 1975

4）植田成文, 松尾晃一, 天野力太：阻血性空腸炎の 1 治験例及び本邦報告例の検討。日臨外医会誌 $44: 1195-1202,1983$

5）平岡 博, 守田信義, 鳥枝道雄汪か：摘脾後腸間膜 静脈血栓症をおこした特発性血小板減少性紫斑病 の 1 例. 日消外会誌 $16 ： 740-743 ， 1983$

6) Broe PJ, Conley CL, Cameron JL: Thrombosis of the portal vein following splenectomy for myeloid metaplasia. Surg Gynecol Obstet $152: 488-492,1981$

7）佐藤太一郎, 七野滋彦, 前田正司经：薬剂性小腸 潰瘍本邦症例と文献的考察. 日消外会誌 11 ： 670-675, 1978

8）加藤岳人，七野滋彦，佐藤太一郎活か：鈍的腹部外 傷による小腸狭窄の 2 例。日消外会誌 16 ： 735-739, 1983

9) Renton CJC: Non-occlusive intestinal infarction. Clin Gastroenterol $1: 655-673,1972$

10) Ottinger LW, Austen WG: A study of 136 patients with mesenteric infarction. Surg Gynecol Obstet 124:251-261, 1967

11) Boley SJ, Krieger H, Schultz $L$ et al: Experimental aspects of peripheral vascular occlusion of the intestine. Surg Gynecol Obstet $121: 789-794,1965$ 